\title{
Myles Brand's Collegiate Model and the Post-Amateurism World of College Sports
}

\author{
Welch Suggs ${ }^{1}$ and Jennifer Hoffman ${ }^{2}$ \\ ${ }^{1}$ University of Georgia, ${ }^{2}$ University of Washington
}

Regrettably few philosophers today become public intellectuals in the manner of Plato or Socrates. Even fewer do so in the field of sport. But perhaps the most influential in the specific realm of college sports, was Myles Brand. Brand spent 15 years on philosophy faculties at the University of Pittsburgh, the University of Illinois at Chicago, and the University of Arizona before moving into the administrative ranks of universities across the country (mylesbrand.com, n.d.).

He was thrust into the national spotlight in 2000 when, as president of Indiana University, he fired Bob Knight, the legendary and tempestuous head men's basketball coach. Two years later, the National Collegiate Athletic Association (NCAA) hired him as president, the first such from a career other than athletic administration.

Brand led the organization for seven years before his untimely death from pancreatic cancer in 2009 . He championed gender equity in sports and diversity in hiring practices. He brought about new measures to assess academic performance and penalize teams whose players did not keep up in the classroom. But a dozen years after his death, Brand's most significant legacy at the NCAA is a clear version of the ideals of what college athletics are and should be, and an attempt to use these ideals to drive policy decisions. He called this the "collegiate model." In his annual addresses at the NCAA convention and other public statements, the collegiate model evolved from a basic formulation of amateurism - with participation being its own reward - to a fully-realized framework embedding the purpose of sports in the purpose of higher education: providing educational experiences, contributing to campus community, engaging the broader public, and contributing to the university's social-justice mission.

In doing so, Brand drew on a century of rhetoric in college and Olympic sports about the idealism of amateur athletics. His contribution was to take elements of older arguments about how college sports were supposed to function and fit them into a coherent paradigm. That paradigm seems most useful for college leaders like Brand himself trying to understand the roles that sport plays on their campuses and the excesses that universities should seek to curb. 
The collegiate model, and the century of debate about college sport that it seeks to make coherent, are based on both the limits of our ideals and aspirations about college sport amid the financial and commercial realities of how sport actually functions in the context of higher education and in American life. "Amateurism," which has been core to the NCAA's mission since the association's founding, was first championed by scholars and advocates in the late nineteenth and early twentieth centuries as the only means of teaching important life lessons through sport, while professional sports were deemed to be irredeemably corrupt. But the reality is that colleges have always used sports, especially big-time sports, as a means of telling institutional stories and connecting with constituents, be they fans, state legislators who control college purse strings, or tuition-paying students.

Brand sought to strip away the problematic aspects of the history of amateurism in his comments while NCAA president about the status of college athletes. He also tried to reconcile the innate conflict between offering sport as an educational opportunity and deploying teams for institutional interests. He never said it publicly, but in doing so Brand seems to be exhorting colleges to adhere to the second formulation of Immanuel Kant's categorical imperative, known to any philosophy student: One should always treat people as ends in themselves, not means to other ends (Kant, 1889). If athletes are treated more like students who happen to perform, perhaps like music students, then they can be shielded from the commercialism accompanying big-time sports (Brand, 2006a).

However, using athletics for institutional marketing has a very long history in higher education strategy. Oberlin College is an early example of how institutions use their athletic programs and facilities for prestige and illustrating their values (Horger, 1996). First opened as Oberlin Collegiate Institute in 1833, it also became the first coeducational institution by admitting women students in 1837 (Oberlin College, 2017). With women's enrollment surpassing men by 1900, Oberlin addressed concerns over men's lower enrollment and corresponding losses in prestige by building the Warner Gymnasium and promoting men's athleticism in 1902 (Horger, 1996).

Thus, the purpose of this paper is threefold, presented here in order: To present the theoretical antecedents of the collegiate model in the histories of both sport and higher education. Second, to articulate the definition of the collegiate model of sport as Brand presented it iteratively in public comments. Third, and finally, is to situate the relevance of the collegiate model as a policy prescription in twenty-first century college sports. The commercialization of college sports that has defined today's moment was primed to accelerate during Brand's tenure at the NCAA. His philosophical approach to defining the collegiate model was not enough to stem the tide of athletic departments turning into juggernauts when it comes to raising and spending money. That process has cast a cold light on amateurism and what it means for athletes today. While the courts and Congress for generations accepted that amateurism was foundational to college sports, judges and legislatures are now affirming that college athletes have economic agency, as they pursue their extracurricular and student interests. 


\section{Background}

Sports emerged on college campuses in the second half of the nineteenth century and became the subject of intense interest both among participants and spectators. Originally organized and led by students, such as the Harvard and Yale boat clubs that participated in the first intercollegiate contest in 1852 at Lake Winnepesaukee, New Hampshire, alumni also became involved as managers of sports teams on many campuses, raising funds and even hiring coaches (Bernstein, 2001; Durick, 1988; Watterson, 2020; Whiton, 1901). In the 1880s and 1890s, faculty asserted control over sports at Harvard and elsewhere, but by the turn of the century, sport was largely under the purview of university administrators. More specifically, it was outside of the faculty and others involved in academic affairs. At the same time, football games and other sports attracted crowds of students and other supporters alike, providing an income stream and platforms for colleges to connect to their alumni and other stakeholders through games in big cities and the construction of immense stadia on campus (Smith, 2008; Watterson, 2020).

\section{The Collegiate Ideal}

At the same time, colleges and universities began to look for more ways to recruit students as the number of institutions expanded. Among the values of this early expansion were the reliance on the ways that a college was a "large family, sleeping, eating, studying, and worshipping together under one roof" (Rudolph, 1990, p. 88). Attending college took on more than just the training for the elite as it expanded into disciplines such as chemistry in preparation for professions such as medicine and teaching.

The extracurriculum took on new importance. By the 1920s "fraternities and social clubs, theater groups, newspapers, and magazines, all of these various enterprises not only allowed young undergraduates to emulate and prepare for life, but also provided them with experiences that they knew to be profoundly human" (Rudolph, 1990, p. 464). Athletic teams, including college football, were "a response to the sterility of the curriculum" in the collegiate era, and in the university era become "competition for the one-sided intellectuality and the overwhelming impersonality of the official scheme of things" (Rudolph, 1990, p. 464).

According to the higher education historian Frederick Rudolph, the extracurriculum "played a major role in sustaining collegiate values" particularly as smaller colleges grew into universities. Clubs, teams, and other activities took on the function of "an agency of the collegiate emphasis on fellowship, character, on well roundedness, and as such, it was a powerful instrument during the period of the 1920s in bringing the university ideal into accommodation with the collegiate ideal" (Rudolph, 1990, p. 464). The collegiate ideal emerged as a critical frame for understanding higher education, where academic life and campus life share equal importance in developing a culture and set of mores for students to carry into later life. 


\section{The Roots of Amateurism}

If the extracurriculum functions as a locus of collegiate values, nothing is a clearer example than the value of amateurism, which became closely associated with college sport. As collegiate sports like track, football, and basketball were formalized at the turn of the century, college leaders espoused a paradigm of sports that drew on three intellectual traditions popular at the time:

1. The Olympic movement, which was claimed to be based on classic Greek ideals of sport

2. The tradition of "Muscular Christianity" popularized in upper-class Protestant circles

3. The belief that play was an important psychosocial developmental activity for both children and adults.

\section{The Olympic Movement}

During this time period, an explicitly class-based movement in sports took place on both sides of the Atlantic. Baron Pierre de Coubertin convened a conference of sporting leaders in Europe and America who co-opted the name and some characteristics of the Olympic Games of classic Greece to launch a new movement in 1896 (although the Greeks themselves had revived the Olympics some years earlier) (Young, 1984). Coubertin wrote that organized sport was a "canker" that inevitably led to corruption and unsportsmanlike conduct in pursuit of victory, but that the Olympics would invite only gentleman as representatives of their own countries, thus counteracting any impulse to cheat in pursuit of victory (Coubertin, 1908). He was inspired in part by Sir John Pentland Mahaffy, a classics scholar at Trinity College in Dublin, Ireland, who traveled in Greece in the 1870s and wrote both about the revival of the Olympics among the Greeks as well as about what he and Coubertin believed to be a distinction between amateur and professional athletics in ancient times. Wrote Mahaffy:

The term "athletic was used by the Greeks for that professional development which they reprehended as the exaggeration of the older gymnastic, with its accompaniment of public games at which the contests were amateur performances, and which were for centuries the glory and pride of Greece (Mahaffy, 1879, p. 63).

The Olympic proposition took root in the nascent NCAA, which was founded in 1906. In an address to the NCAA's annual convention in 1910, R. Tait McKenzie of the University of Pennsylvania applied the Greek term aidos to amateur sport, defining it as the "spirit that should actuate the gentleman amateur," in particular the "scrupulous respect for personal honor and fairness that would make a team elect to risk a probable defeat rather than win through the services of those who do not come within the spirit of a gentleman's agreement" (Mckenzie, 1911, p. 79). This spirit, McKenzie argued, underlaid the ancient Greek ethos of sport competition that culminated in the Olympic Games. It flourished when sport was idealized, but waned as competition became an end in itself rather than a means to the practice of gentlemanly ideals. The Olympic era ended, on McKenzie's account, when sport fell out of 
favor with "the better class of Greeks, who refused to compete with those they considered their social inferiors" (pp. 81-82). McKenzie called on educators to embrace the classical, amateur ideal of sport to promote "honorable and manly competition" as a national norm for the country, "for it is on the two great Anglo-Saxon races that the spirit of competitive sport has descended from the Greeks" (pp. 79-80).

More broadly, modern scholars agree that the interpretation of Olympic athletics as amateur in the Victorian tradition is completely wrong. Mahaffy misconstrues the Greek words he labels "gymnastic" and "athletic," according to Young (1984), and fundamentally misunderstands the character of Greek competitions, including the Olympics. While the Olympics and other tournaments were religious ceremonies, victors in them were rewarded lavishly, and also competed for pay in a variety of other games (Dombrowski, 2009). Moreover, while Mahaffy and McKenzie state that Greek athletics became corrupted when common men began competing and athletes trained specifically for their sports, instead of merely competing as a leisure activity, Young (1984) and Dombrowski (2009) make clear that athletics were extremely serious from the outset. Young is clear in our erroneous assessment of early amateurism and Greek competition: "From Homer on, the concept of amateurism in any sense is wholly foreign, often even antithetical to the nature and vocabulary of Greek athletics" (Young, 1984, p. 164). Young (1984) goes on to assert, "whether or not ancient athletes accepted money for their agonistic achievements has not to do with their nobility or integrity of character" (p. 165). So the path from prizes and pay to corruption is nothing like what the founders of amateur sport would have us believe.

\section{Muscular Christianity}

As college and Olympic sports were coming into being, another, related movement found footing in American culture and particularly in higher education: "Muscular Christianity," as it has come to be known, was a set of beliefs that prioritized physical activity as a means of transmitting moral lessons of hard work and perseverance while also keeping the Anglo-Saxon race strong enough to withstand incursions by others.

Muscular Christianity was a response to early nineteenth-century asceticism, Calvinist suspicion of idle activity, and the rise of women in Protestant church membership. It is important to note that, while exclusive to Protestant males, advocates for "the strenuous life" pronounced it beneficial to all men, not just a favored few of elite physique. Without exercise and the development of fortitude, any man would succumb to mediocrity and dissolution (Putney, 2001). A generation of evangelical coaches like Amos Alonzo Stagg at the University of Chicago used their teams as a platform to preach their views about manhood and how sport could be used for moral education for men (Ladd \& Mathisen, 1999).

While unpaid amateurism was not a specific tenet within the Muscular Christianity movement, the idea that professional athletes would not receive the same moral development seemed to be a common assumption. Stagg, for example, wrote that he turned down several offers to play professional baseball because of his concerns about pro sports (Berg, 1996; Stagg \& Stout, 1927). Proponents of Muscular 
Christianity were particularly enamored with football because they believed rough play — albeit only within the limits of amateur sportsmanship — could develop manhood (Moore, 2015).

\section{Sports and Personal Development through Play}

The third justification for educational sport offered a somewhat more specific justification for amateurism: preserving the "play impulse." A more secular version of moral development through sport espoused by Muscular Christianity, this turn-ofthe-century concept posited that individuals learned from the "play impulse," or lowstakes competition that would allow students to develop skills and ways of thinking and moving (Crowley, 2006). Participating in amateur sports would indulge this play impulse and allow students to develop the desired skills and attributes. Participating in sports for any kind of pay would not, and on this basis the NCAA built up its elaborate code of amateurism.

"The purpose of play, then, viewed as a biological process, is to prepare for life and to furnish a medium for the realization of life," wrote Carl E. Seashore (1910, p. 510). Sport, then could be harnessed in service of this play impulse, preparing participants for the challenges of life. This same concept has been embraced by the service academies. A plaque at West Point proclaims "Upon the fields of friendly strife are sown the seeds that, upon other fields, on other days, will bear the fruits of victory" (U.S. Military Academy, n.d.).

These three strands--arguments that professional sports corrupted the Greeks, the Muscular Christian idea of amateur sport providing a platform for moral education, and the "play impulse" belief that amateur sport provided a space for rehearsing actions for later life - all contributed to the NCAA's principle of amateurism. That principle, which is recorded in the association's Bylaw 2.9 is that:

Student-athletes shall be amateurs in an intercollegiate sport, and their participation should be motivated primarily by education and by the physical, mental and social benefits to be derived. Student participation in intercollegiate athletics is an avocation, and student-athletes should be protected from exploitation by professional and commercial enterprises (National Collegiate Athletic Association, n.d.).

However, there are two basic flaws in this line of thinking. First, as Crowley (2006) notes, the logical conclusion is that participation in sport ought to be a requirement for the entire student body and not merely for the elite athletes competing on football and baseball teams. However, broad participation was never a principle or goal for the NCAA (Crowley, 2006).

More broadly, the psychiatrists and theorists who advocated for moral development through sport participation never actually explained the mechanism by which suiting up on the football field, or building strength and skill through basketball practice, translated to character development. Nor did they offer any evidence of how it was supposed to work. Instead, they cited anecdotes of athletes and built arguments based on religious sources, in the case of Muscular Christianity and the play impulse, or on selective readings of classic Greek culture. No mechanism has 
ever been offered for how physical, mental, and social benefits are conveyed through sport. This is not to say that such benefits do not accrue through participation, but that researchers and practitioners have never answered the basic questions of how? How much? And how much is possible only through sports?

Finally, it is worth noting that to varying degrees, all three of these justifications for amateur sport were explicitly exclusionary toward all but upper-class white male college students. The Olympic ideal excluded professionals as tradespeople who could not receive the intellectual and moral benefits of sport (Young, 1984). Muscular Christianity was explicitly intended to elevate Anglo-Saxon Protestants against cultures of the Mediterranean, Africa, and other potential enemies (Putney, 2001). And the play impulse had its roots and highest meaning in the context of Christianity (Seashore, 1910). Sport remains virtually alone (with Greek systems on some campuses) as sex-segregated activities at colleges and universities. College sport has an even more complicated relationship with race: while a handful of Black, Latino, and Native American athletes participated in football and other sports from the earliest days of competition, southern colleges maintained segregated teams into the 1970s and in many cases refused to allow their teams to compete against integrated teams from northern institutions (Hoberman, 1997; Needham, 1905). That changed as college coaches realized that a significant number of Black football and men's and women's basketball players could be dominant at the top levels of collegiate competition (Hoberman, 1997).

\section{The Implications of Amateurism}

Despite the questionable motives behind these theories and the lack of empirical evidence for them, leaders in college sports continued to espouse the benefits of amateur college sports to participants. However, the NCAA endured decades of conflict between different conferences and members about what was permissible for colleges to offer athletes, and in particular continued scandals about athletes being paid under the table ("subsidized," in the language of the day). In a 1929 report for the Carnegie Commission, Howard J. Savage wrote that "Subsidies for athletic participation are among the first fruits of commercialism. As one bad apple will rot a barrel, so one subsidized athlete will corrupt a school" (Savage et al., 1929, p. 128).

The solutions that evolved were for colleges to provide "legitimate" benefits that were considered uniform across a group of colleges, such that no institution could gain an unfair advantage through providing more compensation. The goal of a "level playing field" in recruiting athletes became bedrock to NCAA rules that exist to this day.

But benefits took different forms. The Big Ten Conference allowed college boosters and others to provide jobs to athletes, some of which were sinecures allowing plenty of time for training (Watterson, 2020). The Southeastern Conference permitted colleges to subsidize education. The NCAA decided that the latter was preferable, permitting colleges to offer educational and living expenses prior to the 1950s, then four-year scholarships in 1957 (Staurowsky \& Sack, 2005). Starting in 1952, NCAA policies increasingly permitted institutions to offer athletic aid and 
eliminated need-based requirements. By 1957, the NCAA defined educational expenses as "tuition and fees, room and board, books, and \$15 per month for laundry" (Sack \& Staurowsky, 1998, p. 47). The NCAA and its members continuously insisted that such educational benefits did not constitute pay and thus did not make athletes employees. Instead, they were students rewarded for the merit they demonstrated as amateurs. It also constrained the costs of recruiting teams of athletes for institutions. The number of scholarships available for each team changed over time, with some sports restricted to only offering a full scholarship to an athlete and others being allowed to divide scholarship funds among a larger number of students.

Over the course of the NCAA's history, its members and apologists made the case that the value of an education, as covered by an athletic scholarship, was reward enough for athletes. Most did not couch it in quite these terms, but the implication was that the education received was compensation for athletes. When the Rev. Theodore M. Hesburgh became president of the University of Notre Dame, he knew that football was inextricably tied to Notre Dame's institutional image, and he did not hesitate to leverage the team's notoriety for institutional benefit. Notre Dame fought the NCAA for its own television deal in the early 1950s, with Hesburgh stating that "television can further widespread public interest in collegiate football, and, what is more important, can promote greater public interest in the educational institutions of which the teams are just one dramatic aspect" (Associated Press, 1953). Notre Dame eventually backed down when the association took steps to expel members who refused to abide by a national contract (Dunnavant, 2004).

In 1949 Hesburgh declared in an address at Notre Dame's football banquet that the sport was not an end in itself, something to be pursued for its own sake, but a means to teach the values of teamwork, cooperation, adaptability to circumstance, and the courage to commit to a game plan (Hesburgh, 1949). In a 1951 essay summarizing the just-past season, he painted a portrait of a football player-young, strong, intelligent; "a person, the son of a father and a mother, somebody's brother" (Hesburgh, 1951, p. 2). He used this to argue players ought to be educated "by developing their heart and spirit than by merely training their reflexes" (p. 4). Here and elsewhere, he implied that there is a covenant between the university and the player - that in exchange for their hard efforts on the field, the university should provide them with the character development they will need for later life. A win-at-all costs mentality will not provide this; nor will it do to

. . . buy a player and then ask him to pose as an amateur for a school; certainly, it is bad to ask a player to exemplify a school's spirit, while preventing him from getting a real education by excessive practice in extra-seasonal activities (Hesburgh, 1951, pp. 4-5).

Hesburgh's work set the stage for periodic "reform" efforts in college sports. Most of these were not directed at the athletes themselves, but instead aimed at the institution - the athletic departments and their stakeholders. Over the course of the 1970s and 1980s, boosters at a number of colleges were accused of paying athletes under the table; the most notable, Southern Methodist University, received the NCAA's death penalty in 1987, vacating a season's record and canceling another. Programs also came under fire for allowing athletes to get by with minimum aca- 
demic achievement, culminating in the spectacle of Dexter Manley, an NFL player, admitting during a Senate hearing that he had never learned to read, neither in school in Houston nor in college at Oklahoma State University (Friend, 1989). As a result, the NCAA instituted controversial academic standards and an independent panel, the Knight Commission on Intercollegiate Athletics, released a report titled "Keeping Faith with the Student-Athlete" that called on colleges to operate with the principles of presidential control of athletics to ensure academic integrity and financial prudence, with an NCAA certification process intended to monitor all three (Knight Commission on Intercollegiate Athletics, 1991). Strikingly, the report does not even include the word "amateur" or discuss pay for athletes; instead it focused on the danger of athletes being "exploited" by their universities in the pursuit of institutional revenue, as the NCAA warns of in its principle of amateurism.

But not everyone was as idealistic about amateurism. In his memoir, former NCAA director Walter Byers questioned all that he had been defending for the majority of his tenure as Executive Director of the NCAA. "We're in a situation where we, the colleges, say it's improper for athletes to get, for example, a new car," he told the Associated Press. "Well, is that morally wrong? Or is it wrong because we say it's wrong?" (Kirshenbaum, 1984).

In a memo to the NCAA's leadership, Byers wrote:

I earnestly hope that the membership does not take a righteous stand in favor of old-time amateur principles for the athletes, but modern-day commercial involvement for coaches and institutions, and somehow expect a relatively small NCAA enforcement crew to keep the situation clean (Byers \& Hammer, 1997, p. 13).

It was his position that colleges were exploiting athletes' talents, and that athletes "deserved the same access to the free market as the coaches enjoyed" (Byers \& Hammer, 1997, p. 13).

Byers was writing at a pivotal moment in the commercial evolution of college sports. In 1984, colleges won the right to negotiate their own football television contracts when the U.S. Supreme Court ruled that television products were a commercial product and thus subject to antitrust laws (National Collegiate Athletic Association v. Board of Regents of Univs. Of Okla. And Ga., 1984). ${ }^{1}$

Following the Regents decision, colleges began negotiating new and highly lucrative contracts to broadcast football games. A group of high-profile institutions first banded together as the College Football Association, but then Notre Dame and the Southeastern Conference broke away to sign their own deals in the early 1990s (Dunnavant, 2004). One by one, leagues took to the marketplace as the NCAA itself began negotiating higher and higher prices for the Division I men's basketball tournament, "March Madness."

\section{Amateurism and the Collegiate Ideal}

As college sports and the concept of amateurism evolved over the course of the twentieth century, so did a paradigm of the extracurriculum, the framing of undergraduate education where academic life and campus life share equal importance and are deeply connected to a sense of place (Toma \& Kezar, 1999). A campus is more 
than just the classrooms and its libraries, it is also the interactions and extracurricular aspects where learning occurs in the social spaces throughout a campus (Fish et al., 2016). From the faculty, to peers, to the librarians, and advisors and staff throughout residence halls, career services, and clubs or student government, the collegiate ideal represents all the learning that occurs on a college campus and in the extracurriculum (Toma, 2003).

Although not dependent on college varsity programs, the collegiate ideal leverages both highly visible and less visible sports. Spectator sports with their high visibility, larger crowds, and attention beyond campus are an outlet for institutional enthusiasm, a vehicle for institutional identity, and a tool for institutional appetite (Toma, 2003; Toma \& Kezar, 1999).

The educational values of the collegiate ideal and the community spectacle of sports are held in tandem with the amateur values of varsity sports. Despite the highly visible, commercial, and professional characteristics of the growing athletic enterprise, women's sports and non-revenue men's sports have become increasingly professional and commercialized while also being held up as more representative of the amateur ideal (Hoffman, 2020; Hoffman et al., 2009).

Thus, the collegiate ideal incorporates amateurism into the broader context of the ineffable, idealistic vision of American higher education. While espousing this ideal, however, college leaders also presided over conferences, athletic departments, and the NCAA itself chasing ever-greater television contracts and stadium revenue to fund their expanding program demands, in addition to dealing with ethical challenges such as bribing recruits and providing athletes with sub-par academic experiences.

In 1997, the NCAA restructured its governance such that instead of a massive convention with each member getting a vote on rules changes, the three divisions voted on separate rules for themselves (Calvin et al., 2019). In Division I, a set of committees consisting of coaches and administrators voted on changes to the rulebook, with a council of presidents - following the Knight Commission's recommendation-getting the final say. Following the terms of Richard Schultz and Cedric Dempsey as executive directors, the NCAA sought a president, and the people who made that decision were themselves college presidents, and so chose one of their own.

\section{Myles Brand and the Collegiate Model}

The NCAA and the public narrative over college sports was well suited to the message of a philosopher and president who had stood up to an abusive coach. The selection of Myles Brand as NCAA president satisfied three priorities of the NCAA in 2003:

1. Maintaining amateurism as a guiding principle

2. Generate revenue sources to fund athletic programs

3. Hold those to account who violate rules over these practices

In his annual "State of the Association" speeches, Brand presented an itera- 
tive definition of what he called the "collegiate model" of sports, as contrasted with a "professional model." Perhaps unsurprisingly, given Brand's background, the speeches take the form of philosophical theory-building. And given the audience for the "State of the Association" - college presidents, athletic directors, and a handful of media - it also is unsurprising that the model Brand presents is primarily a model for how athletic programs ought to operate, rather than a model for the life and career of athletes themselves. Furthermore, the collegiate model as Brand conceptualized it as president of the NCAA, leans on his strength as a public intellectual. He raised the collegiate model as a foundation, a set of values, to frame policy, rather than a practical strategy to guide financial or structural policy change.

In his first State of the Association speech in 2003, shortly after taking office, Brand defined amateurism in the sense "most often understood by the general public" as possessing the "sense of the game for its own value, the feeling of pride in the competition itself, the recognition for local champions" (Brand, 2003, p. 5). The following year, Brand presented a "values-based vision of intercollegiate athletics," with his definitions of the professional and collegiate models (Brand, 2004).

The professional model, on Brand's account, is profit-based, and participants comprise a paid labor force. Teams are loosely tethered to their communities. Brand says he does not disparage this model, but that it is not the appropriate paradigm for college sports. This argument, that distinguishing college sports from professional sports with amateur and student status, draws on Stevens' opinion in Board of Regents v. NCAA which stated that college football television is a distinct product from professional football because of its "unique blend of high-quality athleticism, amateurism, and academic tradition" (Porto, 2012, p. 51).

Instead, the collegiate model is based on education, with participants being students and teams attached to institutions. Brand identifies the key threat as being the "cultural deterioration of fundamental relationship [sic] between college sports and the college campus" in favor of a drift toward professionalism, with athletics programs looking and behaving like freestanding enterprises (Brand, 2004, p. 6). This formulation defines the main purpose of the NCAA: to be the "means by which cooperative action is undertaken in support of the collegiate model" (Brand, 2004, p. 7).

In 2005, Brand stated that to some unidentified critics, amateurism "means athletics on the cheap," that if college athletics were truly amateur, then athletes would be wearing old uniforms and riding buses (Brand, 2005, p. 5). Instead, he said, as long as athletes are bona fide students coming to college to get an education, athletics programs could take advantage of whatever resources they had, including television royalties and shoe contracts, to provide amenities to athletes. In a contemporaneous conversation with the editorial board of The Chronicle of Higher Education, Brand said he believed that if college athletes were paid, college sports would turn into a "cheap minor league" and lose their appeal to the public (personal communication, M. Brand, May 2004).

Brand built on these points in his 2006 address commemorating the NCAA's 
centennial. He stated forthrightly that the bedrock principles of the collegiate model were that athletes were students, not employees, and that athletics programs were "embedded, [are] part of, the university" (Brand, 2006b, p. 7). This follows the Knight Commission on Intercollegiate Athletics' assertion that presidents had to maintain control of athletic programs to ensure their congruence with the educational mission of their institutions (Knight Commission on Intercollegiate Athletics, 1991).

He also challenged the contention that amateurism has its roots in a classist distinction to prevent nineteenth-century college athletes, a minority of the well-to-do, from having to compete against professional athletes. That history, and its association with British universities, was irrelevant to America, he said. As noted before, this does not take into account the explicit class- and race-based arguments made in favor of American amateurism early in the century.

Two years later, Brand began to build out the idea of what athletics in support of education meant. Participating in sports allowed for learning opportunities outside the classroom, developing attitudes and "life plans," and "internalizing the values necessary for happy and fulfilling lives" (Brand, 2007a). Among these values were the drive to pursue excellence, the ability to lead and follow, sportsmanship, commitment to focus and hard work, persistence, and knowing the importance of team and group. As students in classrooms receive skills and information through study, athletes receive these traits and values through practice and competition.

In his final State of the Association address, in 2009, Brand developed these ideas further. Amateur does not mean mediocre, nor does it mean to limit athletics to those who do not need the money, but instead it means that athletes are students first and foremost and thus unpaid (Brand, 2009). He also made his strongest statements yet on the need to prevent athletes from making money, commenting that "NCAA rules are mostly designed to regulate student-athletes" (Brand, 2009, p. 5). Receiving any kind of payment from a university or from endorsing products was verboten for athletes, but most of Brand's attention was focused on colleges themselves not exploiting athletes by requiring them to endorse products. He drew a distinction: marketing teams or universities did not exploit those athletes but putting the face of an athlete on a billboard would, whether or not she was paid.

In sum, across his years at the NCAA, Brand built an argument for the value and validity of college athletics based on two basic principles: athletes were studentsnot employees - and athletic programs were part of higher-education institutions. Neither principle is original. Brand's predecessor Walter Byers asserts in his memoir that the NCAA promulgated the term "student-athlete" in the 1950s to prevent courts from classifying athletes as employees and thus subject to workers' compensation laws (Byers \& Hammer, 1995). The Knight Commission argued for presidential control over intercollegiate athletics, including in particular its budgeting. But Brand integrated these premises into a systematic vision within which college athletics could operate.

However, his two basic principles beg the same question that classic explanations of amateurism did: why should not athletes, even student-athletes, be paid? How would the ways we define and view compensation change or damage the ath- 
lete's experience?

In 2008, Brand and the NCAA pitched the Huffington Post on the idea of the president writing a blog for them. In a series of posts, he developed two arguments against paying athletes (which he shortened to "pay for play"). In one post, he provides the "capitalist" argument: Athletes produce the labor that goes into college sports, so of course they should be paid (Brand, 2008a). Brand answers this by saying that colleges are not operating in a capitalistic environment: They are non-profit organizations maximizing educational opportunities for all students, and programs that drive revenue (i.e., from tuition and state investment) subsidize others that do not. Therefore, college football and men's basketball may be the only sports that can generate revenue in excess of expenses, but that revenue is needed for all of the other expenses not only for those teams but for other athletic programs, ones that do not generate revenue.

In a second post, he presents the "fairness" argument: Everyone else in college sports is making money, particularly high-profile coaches, so why should not athletes get a cut? Brand arrives at the same place as in the prior article by a similar path: Coaching salaries are set by the marketplace, and at the top levels of college sports, universities compete with professional teams for coaches (Brand, 2008b). There is no marketplace, however, for athlete salaries, because most teams make no money beyond the handful of big-time football and men's basketball programs. Therefore, "you can't correct what on the surface appears to be an inequity for a few . . . by creating a worse inequity for the majority" of athletes (Brand, 2008b).

Brand parses salary from compensation and points to external sources as the cause of escalating college football coaching salaries - outside earned income from apparel contracts, television contracts, speaking engagements, and the like. He further notes that among the total number of college coaches only a few in football garner total compensation that runs counter to the amateur ideals of collegiate sports. He affirms that the NCAA is unable to constrain salaries as a matter of policy. He notes the limits on the NCAA's legal authority to cap salaries and calls on campus leaders to wrestle with the question of coaching and market forces.

When discussing coaching salaries and athlete pay, Brand reaffirms amateurism and the distinction it makes between coaches and athletes: Coaches are employees and athletes are students. In an installment from his "Mondays With Myles" podcast series, he notes,

I don't think (coaching salaries are) related at all to whether we pay student athletes. That's a wholly different issue. We don't pay student athletes because they are students. And we don't pay English majors and we don't pay journalist [sic] majors and we don't pay those who participate in athletics. We just don't pay students. They're not employees. They're there to get an education (Brand, 2007b).

Notably, Brand never made the point that many others made about paying athletes: that athlete grants-in-aid, representing a "free education," were compensation enough (e.g., Dorfman, 2013). With tuition, board, books, and fees covered for athletes in some sports, not to mention professional-grade coaching, supplemen- 
tary training, and sports medicine, athletes certainly get a lot of benefits. This fits with Brand's point about athletes and coaches being in different marketplaces, but it leaves out the reality that only a handful of athletes actually receive "full-ride" scholarships that cover all costs.

In another third missive for the Huffington Post, Brand appears to draw on the revenue theory of cost proposed by the economist Howard Bowen: Universities garner all the revenue they can and spend all the revenue they raise on their programs because they are motivated to make those programs better, not to make profits. In sports, athletic departments raise all the money they can for the best facilities and coaches to provide athletes a unique educational experience, not to compensate them with money. Athletes are the "object" of college sports, not "a human resource in the great business machine” (Brand, 2008c).

\section{Legal Challenges to the NCAA's Collegiate Model}

Brand was succeeded by another university president, Mark Emmert, who had led the University of Washington, Louisiana State University, and the University of Connecticut. Emmert almost immediately found himself on the defensive, both legally and culturally, about the NCAA's rules and the status they accorded athletes.

In 2006, a class of athletes led by former Stanford football player Jason White sued the NCAA, alleging that the association's limits on the value of a scholarship violated antitrust law by preventing athletes from receiving funds to cover the full cost of attendance (Baker III et al., 2011). Two years later, the association agreed to settle the lawsuit with payments to former athletes, and in 2015 allowed five leagues - the Atlantic Coast, Big Ten, Big 12, Pacific-Twelve, and the Southeast Conferences - the autonomy to set their own rules regarding financial benefit (Wolohan, 2017). All agreed to enhance the value of a 100\% grant-in-aid to cover the full cost of attendance. While the lawsuit did not ultimately result in a legal finding about the NCAA's amateurism guidelines, it was the first in a series of rulings in which the courts called into question the NCAA's control over defining and deciding what is considered athlete compensation.

The next was a case brought by former UCLA basketball player Ed O'Bannon, who sued over the use of his name and statistics, which the NCAA had licensed to EA Sports to create the "NCAA Basketball" video game (Edelman, 2014). In that case, a district judge called for athletes to be paid an additional $\$ 5,000$ per year for the rights to their names, images, and likenesses (NIL; Wolverton, 2016). An appellate court struck that down, but left in place the district court's finding that the NCAA's amateurism guidelines violated antitrust law (Good, 2016).

In the summer of 2021, the Supreme Court ruled in NCAAv. Alston that the NCAA could not restrict the kind or value of educational benefits colleges could provide to athletes. While the antitrust ruling was relatively narrow, the court expressed deep skepticism about all of the NCAA's restrictions on student aid. Writing for the majority, Justice Neal Gorsuch observed that "no one disputes that the NCAA's 
restrictions in fact [emphasis in the original] decrease the compensation that student-athletes receive compared to what a competitive market could yield" (NCAA v. Alston, 2021, p. 14). Going further, Justice Brett Kavanaugh wrote a concurring opinion to "underscore that the NCAA's remaining compensation rules also raise serious questions under the antitrust laws" (p. 2). He stated that the NCAA's business model would be "flatly illegal" in most other industries, and that the NCAA "cannot avoid the consequences of price-fixing labor into the definition of the product" (pp. $3-4)$. In short, both the majority opinion and the concurrence invite and all but write a road map for athletes to continue chipping away at the NCAA's authority over amateurism in the courts.

Finally, also in the summer of 2021, a raft of state laws took effect allowing current athletes to seek what Ed O'Bannon wanted in retrospect: control and the ability to profit from the use of their NIL. California passed the first Fair Pay to Play Act in 2019 and a flood of states passed legislation in 2021, forcing the NCAA to abrogate its rules preventing athletes from profiting from their NIL rights (Hosick, 2021; McCann, 2021).

All of these challenges to the collegiate ideal came into force as the revenue coming into college sports increased literally exponentially as colleges signed new media deals and brought in more revenue from their stadiums in the years following Brand's passing. Those funds then were poured into new facilities, positions such as videographers and compliance staff, and salaries and severance pay for coaches and administrators. In 2007 the author Rick Bragg noted that the University of Alabama had paid Nick Saban "enough to burn a wet dog" to rescue the Crimson Tide football team, but his annual salary of $\$ 4$ million that year was surpassed by 29 coaches in 2020 (Bragg, 2007; Casagrande, 2017; USA Today, n.d.). As Justice Kavanaugh put it in his concurring opinion, "Those enormous sums of money flow to seemingly everyone except the student-athlete" (NCAA v. Alston, 2021, p. 3).

According to the NCAA's Finances of Intercollegiate Athletics Database, universities with athletic programs in the Power Five (also known as autonomy) conferences of the ACC, Big 10, Big 12, Pac-12, and Southeastern Conference, generated $\$ 8.2$ billion in 2019 (NCAA, n.d.). Of that, 56.4\% (\$4.6 billion) went to coaching and administrative salaries, severance pay, and facilities. Statistics like this complicate any argument by the NCAA that athletes should not be paid.

\section{The Collegiate Model for the 21st Century}

Myles Brand's articulation of the collegiate model and his defense of NCAA rules stressing amateurism over the prior century has fallen victim to three threats: one internal, one external, and a third more insidious. The internal threat is that the collegiate model is based on the premise that the benefits athletes derived from participating in sports could only be obtained if athletes were not compensated. That premise is not based on evidence or even a clear ethical principle. Instead, it evolved purely out of tradition as well as a (possibly purposeful) misreading of Greek history. 
The amateurism premise was never tested, but it will be as the court decisions and legislative action in 2021 reverberate through higher education.

The external threat is that the ideals of the collegiate model have been found lacking when set against the purposes for which universities use athletics programs: to generate revenue and compensate coaches, administrators, and others involved in the enterprise and to raise the profiles of universities when teams are successful. The NCAA and its members apparently did not see this coming; they made no plans for challenges to amateurism until laws were already in place (Wertheim, 2021). But plenty of others did. The legal challenges to the collegiate model and future ones invited by the Supreme Court suggest that it has lost its valence with the public. So too does a poll by Morning Consult, which found that a majority of Americans favored giving athletes the opportunity to profit from the sales of their NIL (Silverman, 2021). In short, the courts and the public appear to have decided that college athletics has failed Kant's categorical imperative by using athletes as means to other ends, rather than as ends in themselves, by allowing colleges, coaches, and administrators to reap massive rewards from athletics while athletes' economic benefits are constrained.

This takes forms beyond just athletes and pay. Long before Brand got to the NCAA, the amateurism ethos spawned a massive rulebook intended to nominally level the playing field by ensuring that all colleges offered recruits and enrolled athletes the same array of benefits. That is, an athlete being recruited in football or basketball at school A would be offered a grant that would cover the same costs that the grant at school B would cover-Northwestern University might be tens of thousands of dollars more expensive than the University of Illinois, but the athlete would not see the cost difference. But the rulebook went on to cover the most picayune of situations, such as the kind of food colleges could offer recruits during visits (Fenno, 2014).

The insidious threat stems from the NCAA's failure to act in situations where colleges did not protect athletes from predators or shielded athletes from punishment when they themselves acted criminally. Baylor University, for example, was accused of covering up sexual assaults committed by football players during the head-coaching tenure of Art Briles (New, 2017). At Michigan State University, a physician working for the women's gymnastics team assaulted a number of athletes over 16 years, but university officials did not act until gymnasts began filing criminal complaints (Lansing State Journal \& Indianapolis Star, n.d.). Neither university, nor others at which similar events took place, ever faced sanction from the NCAA.

As such, it seems clear that not only is amateurism based on the false premise that a relationship exists between the compensation and the educational benefits derived by athletes, but it also has created a system in which petty issues are enforced against the interests of athletes while criminal conduct that affects them goes unscrutinized at the national level. We conclude, then, that college sports are in need of a new model that protects athletes' personal interests and acknowledges their economic ones. 


\section{New Revenue, Need for a New Model}

At the outset of the 2020s, two conditions are clear. First, as in Brand's era, the pressure on athletic departments to capture revenue will continue unabated. In the spring of 2021, the College Football Playoff announced it was exploring an expansion from four teams to 12 , doubling the number of games in the tournament, which in 2019 generated an estimated $\$ 470$ million annually (Hinnen, 2012). What separates the current landscape from Brand's era is the second condition: athletes are acquiring and asserting rights to economic participation in the business of college sports.

Given these economic, legal, and legislative changes, and changing public sentiment over college athlete pay in 2021, American sport seems desperately in need of a new definition of amateurism and, given the NCAA's inability to adapt to the new landscape, quite possibly a new model for sport governance.

We recommend that sport organizations ranging from youth sports to professional organizations and the U.S. Olympic and Paralympic Committee come together to consider a new dichotomy between amateur and professional. There is a role for amateur sports, but it is not to prevent compensation. Instead, it is to promote the educational and personal development of athletes. Brand hinted at this in an article published in the Journal of the Philosophy of Sport when he criticized American higher education for placing academic value on the arts but not on sports (Brand, 2006a). However, the NCAA has arrogated to itself the definition of what a "student-athlete" is: A full-time, traditional-aged undergraduate who must meet not only her institution's academic standards for both admission and continued enrollment but also the NCAA's. And neither the NCAA nor the institution evaluates the outcomes of her experience - the lessons learned from sport, the quality of development provided by coaches and other staff, or any of the other benefits purported to accrue from athletic experience - but only her own inputs in the form of grades, test scores, and progress toward a degree, none of which have anything to with her personal growth in her sporting experience.

Rather than enforcing a thick rulebook defining amateurism and what it permits and forbids, the NCAA could scale back to a league and service organization, maintaining the rules of play, national organization governance, and administering competitions, including championships in the collegiate model. As NCAA President Mark Emmert suggested after the Alston case ruling, colleges or perhaps conferences could decide on the definitions of eligibility and amateurism (Blinder, 2021).

Institutions, then, could decide on whether the definition of a college student eligible for intercollegiate athletics, a definition created more than a century ago, is appropriate for their student populations. However, given the lack of evaluation of the athletic experience, what may also be needed is a separate national organization to provide oversight for athlete welfare and rights, coaching certification, and economic or legal guidance. This might need to be a federal agency, perhaps under the supervision of the U.S. Department of Education or Health and Human Services. 


\section{Conclusion}

We began work on this analysis of Myles Brand's legacy in the spring of 2021, with the Supreme Court's NCAA v. Alston decision looming and states on the brink of enacting legislation permitting athletes to market their NIL. While there is much uncertainty ahead, June 21, 2021 will stand as a marker in the history of college sports just as, if not more, significant than the period of Roosevelt's threat to dismantle college athletics. Where will Myles Brand's legacy fit in this history?

While it is hard to contextualize the current moment while we are still in it, it is also a challenge not to overly historicize Brand and the collegiate model he promoted while at the helm of the NCAA. As a philosopher, his attempt to reconcile the innate conflict between offering sport as an educational opportunity, while relying on teams for institutional marketing and the responsibility of campus community building also warrants historical context.

Ron Smith writes in Play-by-Play: Radio, Television, and Big-time College Sport that from the outset, college and university athletic programs have been tasked with this dilemma: How to offer a highly competitive athletic program that represents the university well, yet do so absent any institutional financial support (Smith, 2010). Both the practical approach and the philosophical dilemmas have been embedded in our system of higher education and our college athletic programs from the start. While Brand did not invent this arrangement, he is in good company for those who were unable to rein in college athletics, no matter how coherent the philosophical argument.

The enterprise of college sports has been remarkably resilient. For a century and a half, college teams have squared off on the premise - and often the myth - that athletes are "merely" undergraduates engaged in an activity for pleasure and for the honor of representing their schools. This premise has held up since the Oxford-Yale boat race in 1852, despite the challenges of cheaters, gamblers, frauds, and other hucksters.

However, it may now succumb to the most powerful force in sports: media. The deluge of money flowing into college sports primarily from broadcasters has permanently ruptured the paradigm that Myles Brand and his predecessors sought to cultivate. But the educational value of sports need not be lost. Instead, if a new paradigm can be established that permits athletes to pursue their professional aspirations while institutions still deliver on their educational ideals, a new model can redeem the checkered history of amateur college sports.

\section{Notes}

1. In the court's opinion, Justice John Paul Stevens wrote that the NCAA "plays a critical role in the maintenance of a revered tradition of amateurism in college sports" (p. 468), but did not specify what amateurism was or how far it extended. In NCAA v. Alston et al., the court specifically ruled that this line in the Regents decision was "dicta," or a stray comment that did not have the force of law (National Collegiate Athletic Association v. Board of Regents of Univs. Of Okla. And Ga., 1984). 


\section{References}

Associated Press. (1953, January 4). Notre Dame hits controlled video. New York Times, S1.

Baker III, T. A., Maxcy, J. G., \& Thomas, C. (2011). White v. NCAA: A chink in the antitrust armor. Journal of the Legal Aspects of Sport, 21, 75-99.

Berg, P. I. (1996). A mission on the Midway: Amos Alonzo Stagg and the gospel of football [Ph.D., Michigan State University]. In ProQuest Dissertations and Theses (304252509). ProQuest Dissertations \& Theses A\&I; ProQuest Dissertations \& Theses Global. https:/www.proquest.com/dissertations-theses/mission-on-midway-amos-alonzo-stagg-gospel/docview/304252509/se-2?accountid $=14537$

Bernstein, M. F. (2001). Football: The Ivy League origins of an American obsession. University of Pennsylvania Press.

Blinder, A. (2021, July 15). N.C.A.A. chief, under pressure, says college sports may need reorganization. The New York Times. https:/www.nytimes.com/2021/07/15/ sports/mark-emmert-ncaa-reorganize-supreme-court.html

Brand, M. (2003, January 1). NCAA State of the Association. https://mylesbrand. com/wp-content/uploads/2003/01/2003-NCAA-State-of-the-Association.pdf

Brand, M. (2004). Value-based educational model. NCAA State of the Association delivered at 2004 NCAA Convention. https://mylesbrand.com/wp-content/uplo ads/2004/01/2004-NCAA-State-of-the-Association.pdf

Brand, M. (2005). The myths of college sports: Debunking the four great commonly held misperceptions about intercollegiate athletics. NCAA State of the Association delivered at 2005 NCAA Convention. https://mylesbrand.com/wp-content/ uploads/2005/01/2005-NCAA-State-of-the-Association.pdf

Brand, M. (2006a). The role and value of intercollegiate athletics in universities. Journal of the Philosophy of Sport, 33(1), 9-20.

Brand, M. (2006b, January 16). NCAA State of the Association 2006. https://mylesbrand.com/wp-content/uploads/2006/01/2006-NCAA-State-of-the-Association.pdf

Bragg, R. (2007, August 27). In the Nick of time: Alabama's football faithful welcome their savior. Sports Illustrated. https://www.si.com/college/2014/08/31/ nick-saban-bear-bryant-alabama-crimson-tide-si-60

Brand, M. (2007a). In all, fairness. NCAA State of the Association delivered at 2007 NCAA Convention. https://mylesbrand.com/wp-content/uploads/2007/01/2007 -NCAA-State-of-the-Association.pdf

Brand, M. (2007b, January 22). Episode 40: Coaches' compensation. Mondays with Myles. https://mylesbrand.com/audio/page/5/

Brand, M. (2008a, September 6). Why the capitalism argument on pay for play doesn't work. Huffington Post. https://mylesbrand.com/wp-content/uploads/2021/02/96-2008-Huffington-Post-Pay-for-Play-II.pdf

Brand, M. (2008b, September 12). Why the fairness argument on pay for play isn't a fair argument. Huffington Post. https://mylesbrand.com/wp-content/uploads/2021/02/9-12-2008-Huffington-Post-Pay-for-Play-III.pdf 
Brand, M. (2008c, August 20). Pay for play is fine - but not in college sports. Huffington Post. https://mylesbrand.com/wp-content/uploads/2021/02/8-20-2008Huffington-Post-Pay-for-Play-I.pdf

Brand, M. (2009). The challenges of commercial activity. NCAA State of the Association delivered at 2009 NCAA Convention. https://mylesbrand.com/wp-content/uploads/2009/01/2009-NCAA-State-of-the-Association.pdf

Byers, W., \& Hammer, C. H. (1997). Unsportsmanlike conduct: Exploiting college athletes. University of Michigan Press.

Calvin, N., Abiodun, I., \& Marvin, W. (2019). The evolving institutional work of the National Collegiate Athletic Association to maintain dominance in a fragmented field. Sport Management Review, 22(3), 379-394.

Casagrande, M. (2017, May 3). History of Saban's rising pay, how it's been viewed. Al.com. https://www.al.com/alabamafootball/2017/05/the 10-year history of nick sa.html

Coubertin, P. (1908). Why I revived the Olympic Games. The Fortnightly Review, $90,110-115$.

Crowley, J. N. (2006). In the arena: The NCAA's first century. National Collegiate Athletic Assn.

Dombrowski, D. A. (2009). Contemporary athletics and ancient Greek ideals. University of Chicago Press.

Dorfman, J. (2013, August 13). Pay college athletes? They're already paid up to $\$ 125,000$ per year. Forbes. https:/www.forbes.com/sites/jeffreydorfman/2013/08/29/pay-college-athletes-theyre-already-paid-up-to-125000year/

Dunnavant, K. (2004). The fifty-year seduction: How television manipulated college football, from the birth of the modern NCAA to the creation of the BCS. MacMillan.

Durick, W. G. (1988). The gentlemen's race: An Examination of the 1869 Harvard-Oxford boat race. Journal of Sport History, 15(1), 41-63.

Edelman, M. (2014). The district court decision in O'Bannon v. National Collegiate Athletic Association: A small step forward for college-athlete rights, and a gateway for far grander change. Wash. \& Lee L. Rev., 71, 2319-2364.

Fenno, N. (2014, February 19). Three Oklahoma athletes penalized by university for eating pasta. Los Angeles Times. https://www.latimes.com/sports/la-xpm-2014feb-19-la-sp-sn-three-oklahoma-athletes-penalized-over-pasta-20140219-story. html

Fish, M. C., Gefen, D. R., Kaczetow, W., Winograd, G., \& Futtersak-Goldberg, R. (2016). Development and validation of the college campus environment scale (CCES): Promoting positive college experiences. Innovative Higher Education, 41(2), 153-165.

Friend, T. (1989, July 2). The education of Dexter Manley. The Washington Post. https://www.washingtonpost.com/archive/lifestyle/magazine/1989/07/02/theeducation-of-dexter-manley/84ba83c2-cbf0-45f2-b636-d644c5224d4a/

Good, O. S. (2016, March 15). EA Sports NCAA Football settlement's average payment will be about $\$ 1,600$ per player. Polygon. https://www.polygon. com/2016/3/15/11242004/ncaa-football-settlement-payout-ea-sports 
Hesburgh, T. (1949). Untitled draft of football banquet address [Archives, University of Notre Dame]. Rev. Theodore M. Hesburgh, C.S.C.: Speeches. http://archives. nd.edu/Hesburgh/UDIS-H1-35-01.pdf

Hesburgh, T. (1951). Undated draft of essay/speech following the 1951 season [U. of Notre Dame Archives]. Rev. Theodore M. Hesburgh, C.S.C.: Speeches. http:// archives.nd.edu/Hesburgh/CPHS141-01-02.pdf

Hinnen, J. (2012, November 21). ESPN reaches 12-year deal to air college football playoffs. CBSSports.com. https://www.cbssports.com/college-football/news/espn-reaches-12-year-deal-to-air-college-football-playoffs/

Hoberman, J. M. (1997). Darwin's athletes: How sport has damaged Black America and preserved the myth of race. Houghton Mifflin Harcourt.

Hoffman, J. L. (2020). College sports and institutional values in competition: Leadership Challenges. Routledge.

Hoffman, J. L., Iverson, S. V., Allan, E. J., \& Ropers-Huilman, R. (2009). Title IX policy and intercollegiate athletics: A feminist poststructural critique. In E.J. Allan, S. Iverson, \& R. Ropers-Huilman (Eds.), Reconstructing policy in higher education (pp. 149-166). Routledge.

Horger, M. (1996). Basketball and athletic control at Oberlin College, 1896-1915. Journal of Sport History, 23(3), 256-283.

Hosick, M. B. (2021, June 30). NCAA adopts interim name, image and likeness poli$c y$ [Text]. NCAA.org. http://www.ncaa.org/about/resources/media-center/news/ ncaa-adopts-interim-name-image-and-likeness-policy

Kant, I. (1889). Kant's critique of practical reason and other works on the theory of ethics. Longmans, Green.

Kirshenbaum, J. (1984, September 17). Scorecard. Sports Illustrated. https://vault. si.com/vault/1984/09/17/scorecard

Knight Commission on Intercollegiate Athletics. (1991). Keeping faith with the student-athlete. https://www.knightcommission.org/wp-content/uploads/ 2008/10/1991-93 kcia report.pdf

Ladd, T., \& Mathisen, J. (1999). Muscular Christianity: Evangelical Protestantism and the development of American sport. BridgePoint Books.

Lansing State Journal, \& Indianapolis Star. (n.d.). Who is Larry Nassar? Timeline of his career, prison sentences. USA TODAY. https://www.usatoday.com/pages/ interactives/larry-nassar-timeline/

Mahaffy, J. P. (1879). Old Greek athletics. Macmillan's Magazine, 36, 61-69.

McCann, M. (2021, June 24). NCAA to let schools and states set athlete NIL pay rules amid 'guidance.' Sportico.com. https://www.sportico.com/law/analysis/2021/ncaa-nil-rules-2-1234632642/

Mckenzie, R. T. (1911). The chronicle of the amateur spirit. American Physical Education Review, 16(1), 79-94.

Moore, J. (2015, May 8). Muscular Christianity and American sport's undying love of violence. The Guardian. http://www.theguardian.com/sport/blog/2015/ may/08/muscular-christianity-and-american-sports-undying-love-of-violence

mylesbrand.com. (n.d.). About Myles Brand. https://mylesbrand.com/about-mylesbrand/ 
National Collegiate Athletic Association v Alston et al., (U.S. Supreme Court June 21, 2021). https://www.supremecourt.gov/opinions/20pdf/20-512_gfbh.pdf

National Collegiate Athletic Association v. Board of Regents of Univs. Of Okla. And Ga., 468 US 85 (U.S. Supreme Court 1984).

National Collegiate Athletic Association. (n.d.). Bylaw 2.9. Legislative Services Database. https://web3.ncaa.org/lsdbi/bylaw?bylawId=2470\&division=1\&adopt$\underline{\mathrm{ed}=0}$

National Collegiate Athletic Association. (n.d.). Finances of intercollegiate athletics database. (n.d.). https://www.ncaa.org/about/resources/research/finances-intercollegiate-athletics-database

Needham, H. B. (1905). The college athlete: How commercialism is making him a professional. McClure's Magazine, 25(2), 121-128.

New, J. (2017, February 9). Baylor not alone in shielding athletes accused of misconduct from punishment. InsideHigherEd.com. https:/www.insidehighered.com/ news/2017/02/09/baylor-not-alone-shielding-athletes-accused-misconduct-punishment

Oberlin College. (2017, February 23). Oberlin history. Oberlin College and Conservatory. https://www.oberlin.edu/about-oberlin/oberlin-history

Porto, B. (2012). The Supreme Court and the NCAA: The case for less commercialism and more due process in college sports. University of Michigan Press.

Putney, C. (2001). Muscular Christianity: Manhood and sports in Protestant America, 1880-1920. Harvard University Press.

Rudolph, F. (1990). The American college and university: A history. University of Georgia Press.

Sack, A. L., \& Staurowsky, E. J. (1998). College athletes for hire: The evolution and legacy of the NCAA's amateur myth. Praeger.

Savage, H. J., Bentley, H. W., McGovern, J. T., \& Dean, F. S. (1929). American college athletics. Carnegie Foundation for the Advancement of Teaching Bulletin, 23.

Seashore, C. (1910). The play impulse and attitude in religion. The American Journal of Theology, 14(4), 505-520.

Silverman, A. (2021, June 29). From name, image and likeness to pay for play, Americans increasingly support compensation for college athletes. Morning Consult. https://morningconsult.com/2021/06/29/nil-college-athletes-compensation/

Smith, R. A. (2008). Far more than commercialism: Stadium building from Harvard's innovations to Stanford's 'Dirt Bowl.' The International Journal of the History of Sport, 25(11), 1453-1474.

Smith, R. A. (2010). Play-by-play: Radio, television, and big-time college sport. Johns Hopkins University Press.

Stagg, A., \& Stout, W. (1927). Touchdown. Longmans.

Staurowsky, E. J., \& Sack, A. L. (2005). Reconsidering the use of the term student-athlete in academic research. Journal of Sport Management, 19(2), 103116. 
Toma, J. D. (2003). Football U.: Spectator sports in the life of the American university. University of Michigan Press.

Toma, J. D., \& Kezar, A. J. (Eds.). (1999). Reconceptualizing the collegiate ideal. Jossey-Bass.

USA Today. (n.d.). College football head coach salaries. https://sports.usatoday. com/ncaa/salaries/

U.S. Military Academy. (n.d.). Company athletics. https://www.westpoint.edu/athletics/company-athletics

Watterson, J. S. (2020). College football: History, spectacle, controversy. JHU Press.

Wertheim, J. (2021, June 29). Q\&A: Prominent attorney on NCAA's SCOTUS shutout, NIL. Sports Illustrated. https://www.si.com/college/2021/06/29/ncaa-scotus-nil-jeffrey-kessler

Whiton, J. (1901). The first Harvard Yale Regatta (1852). New Outlook, 68(1), 286289. https://books.google.com/books?id=t4sxAQAAMAAJ

Wolohan, J. T. (2017). What is reasonable: Are the NCAA's restraints on athlete compensation reasonable? Syracuse L. Rev., 67, 515-549.

Wolverton, B. (2016, October 4). Court's refusal to hear O'Bannon case leaves player-pay issue unsettled. The Chronicle of Higher Education. https://www. chronicle.com/article/courts-refusal-to-hear-obannon-case-leaves-player-payissue-unsettled/

Young, D. C. (1984). The Olympic myth of Greek amateur athletics. Ares Publishers Inc. 